\title{
Glacier mass loss induced the rapid growth of Linggo Co on the central Tibetan Plateau
}

\author{
Yanbin LEI, ${ }^{1}$ Tandong YAO, ${ }^{1}$ Chaolu $\mathrm{YI}^{1}{ }^{1}$ Weicai WANG, ${ }^{1}$ Yongwei SHENG, ${ }^{2}$ Junli $\mathrm{LI}^{2}{ }^{2}$ \\ Daniel JOSWIAK ${ }^{1}$
}

\author{
${ }^{1}$ Key Laboratory of Tibetan Environment Changes and Land Surface Processes, Institute of Tibetan Plateau Research, \\ Chinese Academy of Sciences, Beijing 100085, China \\ E-mail: tdyao@itpcas.ac.cn \\ ${ }^{2}$ Department of Geography, University of California, Los Angeles, CA 90095-1524, USA
}

\begin{abstract}
Remote-sensing and GIS techniques in conjunction with field investigations show how glacier mass loss has led to the rapid growth of Linggo Co, a glacier-fed lake on the central Tibetan Plateau, which has expanded by $21.3 \%$ in area between 1974 and 2010, with a lake-level rise of $\sim 11.2 \mathrm{~m}$. The lake volume of Linggo Co increased at a rate of $0.02 \times 10^{6}, 42.67 \times 10^{6}$ and $65.8 \times 10^{6} \mathrm{~m}^{3} \mathrm{a}^{-1}$ during the periods 1974-92, 1992-99 and 1999-2010, respectively. Other nonglacier-fed lakes in the vicinity (i.e. Longwei Co, Amur Co and Darngo Co Ngion) shrank considerably from the early 1970s to 1992 and then expanded from 1992 to 2010 . Despite being in the same climate region, Linggo $\mathrm{Co}$ and the non-glacier-fed lakes have differed in response to climate change. The glaciers in the catchment of Linggo Co retreated by $2.4 \%$ in area between 1974 and 2007, and their mean thickness decreased by $6.19 \pm 1.91 \mathrm{~m}$ between 1974 and 2000 , with an associated glacier meltwater runoff of $(7.52 \pm 2.32) \times 10^{8} \mathrm{~m}^{3}$. The results indicate that glacier mass loss had a significant impact on the growth of Linggo Co over the past 40 years.
\end{abstract}

\section{INTRODUCTION}

Global warming has significantly impacted the cryosphere in recent decades. According to the fourth Intergovernmental Panel on Climate Change assessment report (Solomon and others, 2007), there has been considerable mass loss of glaciers and ice caps across the planet since the 1960s. Globally averaged mass balance from glaciers and ice caps from 1960 to 2004 is about $-12.2 \times 10^{3} \mathrm{~kg} \mathrm{~m}^{-2} \mathrm{a}^{-1}$, equivalent to about $-14 \mathrm{~m}$ of ice. Owing to rising temperatures, glacier mass loss rates from 1990 to 2004 were roughly double those from 1960 to 1990 . The global mass loss of glaciers and ice caps is estimated to be $0.50 \mathrm{~mm} \mathrm{a}^{-1}$ in sea-level equivalent (SLE) from 1961 to 2004, and $0.77 \mathrm{~mm} \mathrm{a}^{-1}$ SLE from 1991 to 2004.

Encompassing the source regions of many large rivers, the cryosphere on the Tibetan Plateau (TP) plays an important role in the water cycle of Southeast Asia (Shi, 2001; Yao and others, 2004). Global warming has influenced the environment on the TP significantly over recent decades, causing glacier retreat (Racoviteanu and others, 2008; Kang and others, 2009; Schmidt and Nüsser, 2009), permafrost degradation (Li and others, 2008; Liu and others, 2009), snow-cover decrease (Qin and others, 2006; Solomon and others, 2007), etc. It is estimated that glaciers in western China underwent a $5.5 \%$ area loss (Kang and others, 2009), and their mean thickness decreased by $6.8 \mathrm{~m}$ from 1960 to 2000 (Yao and others, 2004). Consequently, the glacial mass loss since the 1990s has caused an increase of $5.5 \%$ in river runoff and a change in hydrological processes in northwestern China, particularly on the TP (Yao and others, 2004, 2007).

Negative mass balance of glaciers and ice caps can lead to the growth of inland lakes (Yao and others, 2010). However, it is difficult to evaluate the impact of glacier mass loss on lake-level rise since not all the glacier meltwater is transferred into lakes. Glacier meltwater experiences evaporation and catchment infiltration before reaching lakes. In studies of sea-level rise, glacier mass loss and sea-level rise are usually directly compared, assuming that the mass loss of glaciers and ice caps is entirely transferred to the ocean (Solomon and others, 2007).

The TP encompasses the world's largest group of highaltitude lakes, with a total lake area of $\sim 40000 \mathrm{~km}^{2}$, accounting for nearly half of the total lake area in China (Guan and others, 1984). Many studies show that lakes on the central TP expanded slightly between 1970 and 2000, but expanded dramatically after 2000 (Liu and others, 2009; Bian and others, 2010; Wan and others, 2010; Zhu and others, 2010). The increase in lake area over the past 10 years is much larger than that between 1970 and 2000, the causes of which remain unclear.

In this study, we evaluated the impact of glacier mass loss on the growth of Linggo Co ('Co', pronounced 'tso', is the Tibetan word for lake), an inland glacier-fed lake on the central TP, by comparing the variations of this lake with the surrounding non-glacier-fed lakes between the 1970s and 2010. Lake volume variations were estimated from lake boundaries at different stages and bathymetric data from field investigations. Glacier volume variations were obtained by calculating glacier surface elevation differences between the 1970s and 2000. This study provides insight into the influence of glacier mass loss on lake growth on the TP over the past four decades.

\section{STUDY SITES}

Linggo Co lies within an $1830 \mathrm{~km}^{2}$ closed basin west of the Tanggula Mountains on the central TP (Fig. 1). Meltwater from the Puruogangri ice field, $40 \mathrm{~km}$ to the east, is its primary water source. In 1974, the lake had a surface area of 


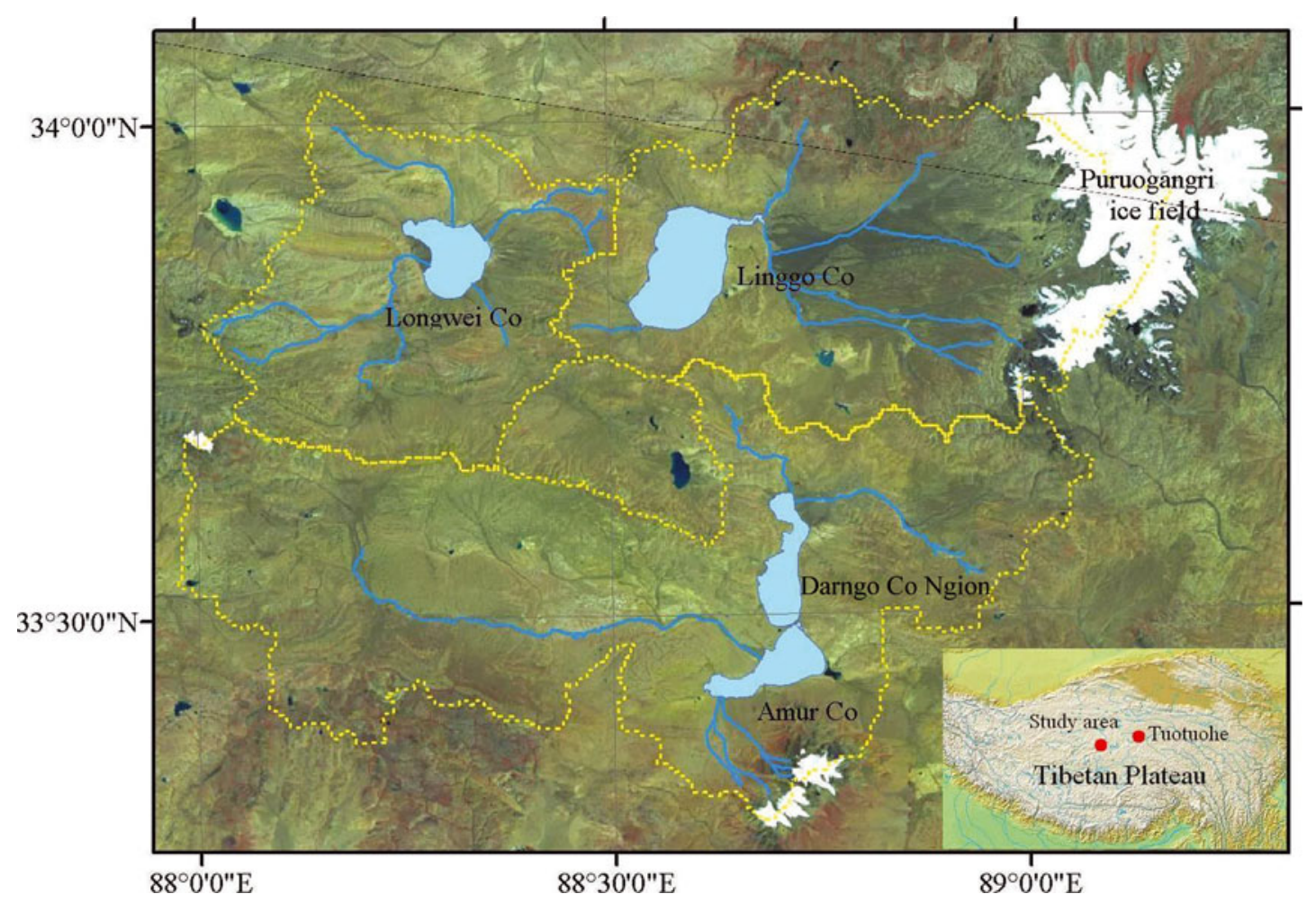

Fig. 1. Location of the study area. Yellow lines are the lake catchment boundaries.

$\sim 95 \mathrm{~km}^{2}$ at $\sim 5060 \mathrm{~m}$ a.s.l. The Puruogangri ice field has an area of $\sim 422.6 \mathrm{~km}^{2}$ (Pu and others, 2002; Yi and others, 2002), of which $135 \mathrm{~km}^{2}$ lies in the catchment of Linggo Co. Owing to harsh natural conditions, the region is virtually uninhabited. Tuotuohe meteorological station, the closest station to Linggo Co, is located about $330 \mathrm{~km}$ to the northeast. According to a regional map (Sun and others, 1990), the mean annual temperature around Linggo Co is about $-6^{\circ} \mathrm{C}$, and the mean summer temperature is close to $0^{\circ} \mathrm{C}$. Total annual precipitation is estimated to be 150 $200 \mathrm{~mm}$, with $70-80 \%$ of snowfall occurring in the summer (Li and others, 2006).

Other lakes in the vicinity of Linggo Co include Longwei Co, Amur Co and Darngo Co Ngion (Fig. 1). Longwei Co, about 20-30 km west of Linggo Co (Fig. 1), had a surface area of $\sim 44 \mathrm{~km}^{2}$ in 1973 and an elevation of $\sim 4924 \mathrm{~m}$. This lake has a catchment area of $1200 \mathrm{~km}^{2}$, with gentle slopes to the east and a large alluvial fan to the west. There is no glacier in the catchment of Longwei Co. South of Linggo Co, a low bank several meters in height separated Darngo Co Ngion from Amur Co before 1999, but satellite imagery in 2006 shows that they became a single lake due to lake-level rise. Darngo Co Ngion and Amur Co share a catchment area of $2740 \mathrm{~km}^{2}$ and in 1971 had surface areas of $\sim 41$ and $\sim 34 \mathrm{~km}^{2}$ respectively. Several small glaciers, with a total area of about $8 \mathrm{~km}^{2}$, are distributed in the catchment of Amur Co and Darngo Co Ngion.

\section{DATA AND METHODS}

\section{Remote-sensing data}

Satellite images were used to monitor lake and glacier changes. We acquired six scenes of Landsat images, including one Multispectral Scanner (MSS) image on
2 December 1976, one Thematic Mapper (TM) image on 30 September 1992 and four Enhanced Thematic Mapper Plus (ETM+) images on 25 August 1999, 21 September 2003, 29 September 2006 and 7 August 2010. All satellite images were co-registered to 1:100000 topographic maps produced from early 1970 s aerial photography. The coregistration errors to the maps were within one image pixel. All map and image data were projected into the UTM (Universal Transverse Mercator) coordinate system zone 45 using the WGS84 geodetic datum. Glaciers and lakes on the $1: 100000$ scale topographic maps and sequential Landsat images were extracted in the false-color image by on-screen digitizing with manual delineation using ArcGIS 9.2 software. The accuracy of manual digitization was controlled within one pixel.

It is more challenging to extract glacier boundaries than lake boundaries because glaciers are often covered by snow at high elevations (Ye and others, 2008). In 1999 and 2007 images, a $\sim 10 \mathrm{~km}$ long section of the southwest Puruogangri ice field was covered by snow, which made it difficult to differentiate the glacier boundary. For this study, we assumed that the glacier boundary remained unchanged, and used the same data at different stages for the snow-covered portions to calculate the glacier area. The boundaries of glacier tongues that are covered by debris are usually difficult to detect. However, field investigation shows that debris does not cover the glacier snouts on the western side of the Puruogangri ice field ( $\mathrm{Pu}$ and others, 2002).

We used digital elevation model (DEM) data from 1974 and 2000 to evaluate the glacier mass loss. The DEM of 1974 (hereafter DEM10) was created by digitizing 40 m equidistant contour lines on 1:100000 topographic maps. The DEM from 2000 was Shuttle Radar Topography Mission (SRTM) version 4.1, obtained from the Consortium for Spatial Information of the Consultative Group for International 


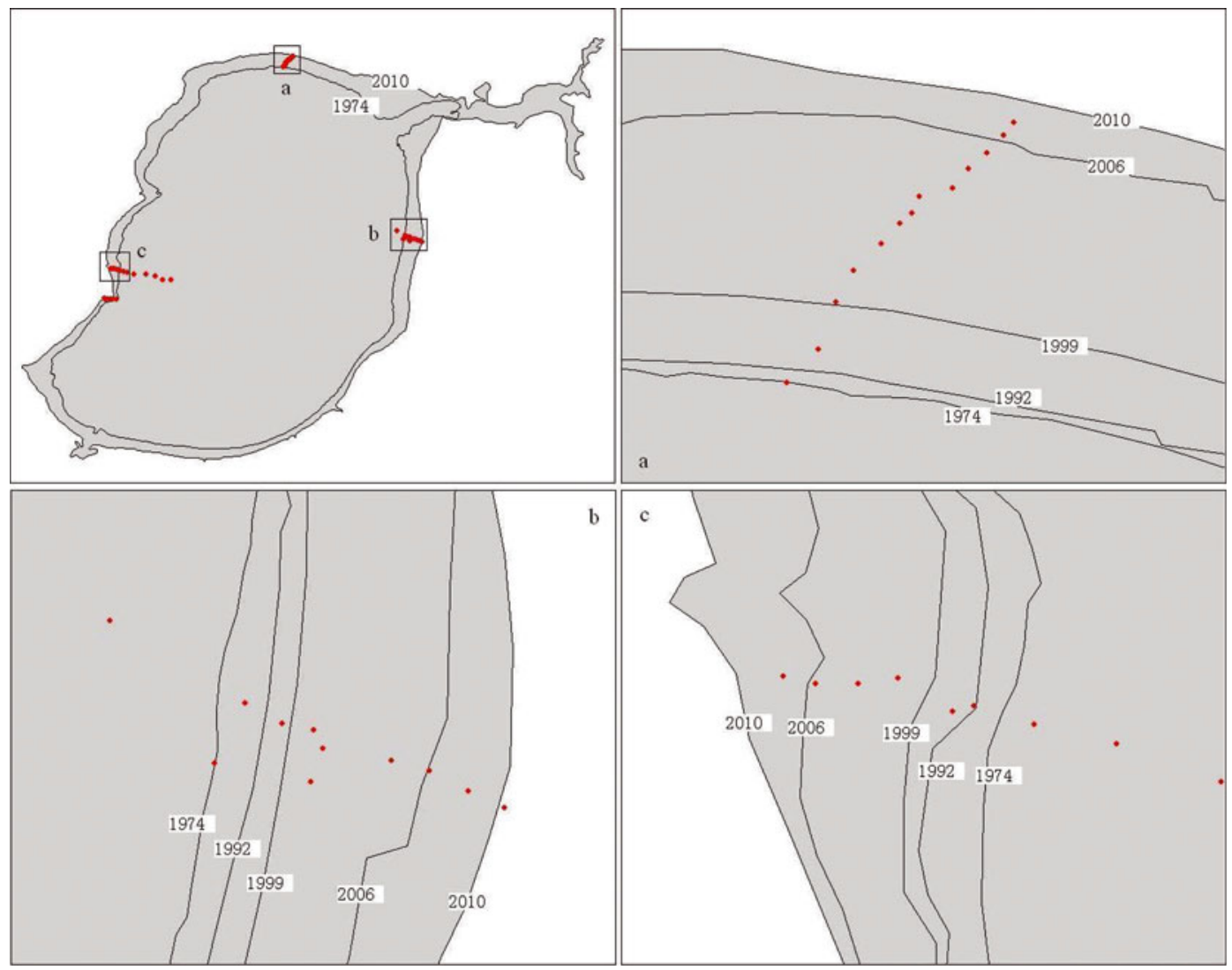

Fig. 2. The growth of Linggo Co between 1974 and 2010, and three bathymetric profiles perpendicular to the shoreline (a, b, c). The gray area shows the lake water in 2010. The lake boundaries in 1974, 1992, 1999 and 2006 are also marked. The red dots indicate the sites for water depth measurement.

Agricultural Research (CGIAR-CSI) SRTM $90 \mathrm{~m}$ database (http://srtm.csi.cgiar.org/). The voids in SRTM in this version were filled prior to download using methods described by Reuter and others (2007). The Puruogangri ice field study area was free of voids in comparison with the original data of the SRTM DEM. In order to eliminate the possible impact of geometric errors between the two DEMs, the SRTM was coregistered to DEM10 (Wang and others, 2012). The elevation change of the ice field from 1974 to 2000 was obtained by subtracting the DEM10 from the SRTM.

It is important to note that there is some uncertainty in deriving glacier elevation change using DEM comparisons. The standard deviation, SD, in non-glacial areas can be used as a first estimate of the uncertainty, but will probably overestimate it (Berthier and others, 2007). Here we use the standard error, SE, and the mean elevation difference, MED, in non-glacier areas as an estimate of the uncertainty, $e$, according to the law of error propagation (Koblet and others, 2010; Nuth and Kääb, 2011)

$$
e=\sqrt{(\mathrm{MED})^{2}+(\mathrm{SE})^{2}}
$$

SE is defined as the SD of non-glacial areas divided by the square root of the degree of freedom (sometimes called 'effective sample size'). MED can be considered to be the systematic uncertainty of volume changes for the corresponding time period, while SE is the corresponding stochastic uncertainty. In calculating MED we took all the non-glaciated DEM gridcells into consideration, and while calculating SE we assumed an autocorrelation distance of $1.8 \mathrm{~km}$ (20 pixels) (Koblet and others, 2010). The error in elevation differences for the glaciated areas was estimated to be $\pm 1.91 \mathrm{~m}$. Volume change was calculated according to the glacier area in 1974, assuming that the density profile remained unchanged. To convert volume change into mass change, we assumed an ice density of $900 \mathrm{~kg} \mathrm{~m}^{-3}$.

\section{Field investigations}

Field campaigns to the lakes were conducted in November of 2009 and 2010. Three bathymetric transects in Linggo Co were surveyed at intervals of 50-100 m perpendicular to the shoreline, where the slope of the lake bed is relatively gentle (Fig. 2). The water depth was determined using an ultrasonic instrument (MD-100) with an uncertainty of less than $0.3 \%$. Lake-level variations were determined according to the lake boundary at different stages and the bathymetric profile survey in 2010/2009, with the lake level in 2010/2009 as the reference. The lake boundaries were determined with an uncertainty of one pixel for TM and ETM+ images (28.5 m). The error range of these measurements suggests that the accuracy of our calculated lake-level variation is adequate for evaluating the lake evolution along three long transects.

\section{RESULTS AND DISCUSSION}

\section{Lake changes}

The area of Linggo Co increased by a total of $20.26 \mathrm{~km}^{2}$ $(21.34 \%)$, with the rate of growth accelerating between 1974 and 2010 (Table 1; Fig. 3). The lake area was $94.95 \mathrm{~km}^{2}$ in 1974 and increased by $2.64 \mathrm{~km}^{2}$ (2.78\%) from 1974 to 1992 . It continued to increase, by $3.76 \mathrm{~km}^{2}(3.96 \%)$, 


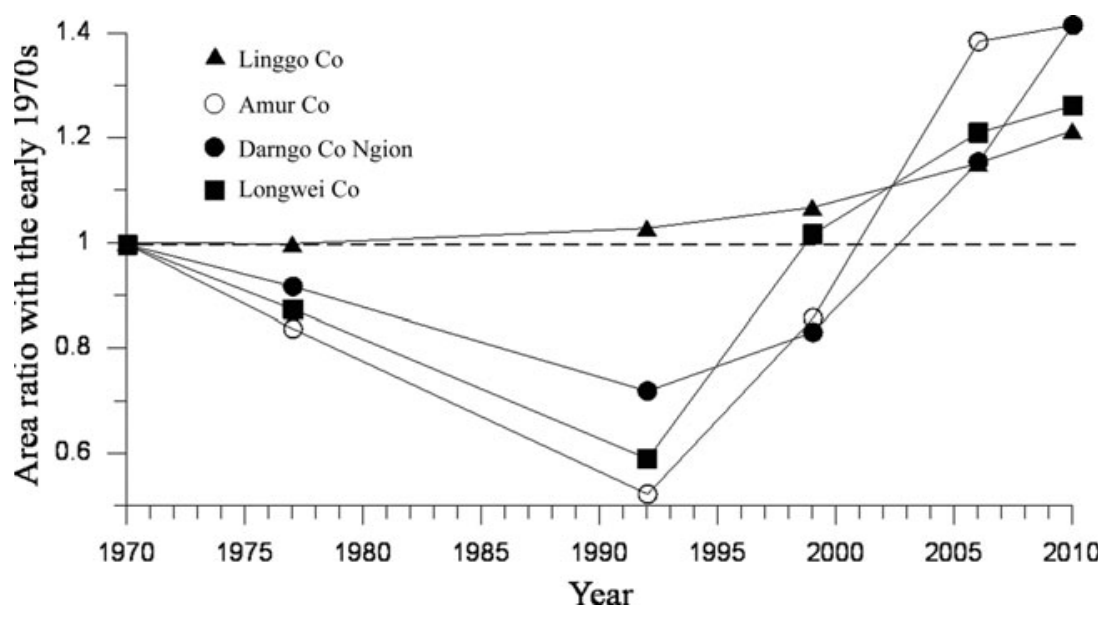

Fig. 3. The lake area ratios of the four studied lakes at different stages, compared with the early 1970s (see Table 1).

from 1992 to 1999. Between 1999 and 2010, the lake area increased significantly by $13.86 \mathrm{~km}^{2}(14.60 \%)$, at a much higher rate than during previous observational periods.

Lake-level variation was reconstructed according to the lake boundaries at different stages and the corresponding water depth in 2009/2010 (Fig. 4). The water level of Linggo Co rose by $1.5 \mathrm{~m}\left(8.3 \mathrm{~cm} \mathrm{a}^{-1}\right)$ between 1974 and 1992, by

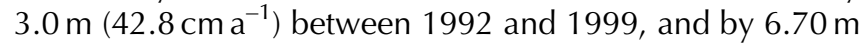
$\left(60.9 \mathrm{~cm} \mathrm{a}^{-1}\right)$ between 1999 and 2010 . Thus, Linggo Co rose by $11.2 \mathrm{~m}$ between 1974 and 2010, and the most prominent increase in lake level occurred between 1999 and 2010.

By assuming for simplicity that the lake basin is coneshaped, the variation of lake volume can be expressed as

$$
\Delta V=\frac{1}{3} \times\left(S_{1}+\sqrt{S_{1} \times S_{2}}+S_{2}\right) \times h,
$$

where $S_{1}$ and $S_{2}$ are the lake area at two stages and $h$ is the change in water level. Based on the lake area at different stages and lake-level variation, we estimated that the lake volume of Linggo Co increased by $1.44 \times 10^{8} \mathrm{~m}^{3}(8.02 \times$ $10^{6} \mathrm{~m}^{3} \mathrm{a}^{-1}$ ) between 1974 and 1992 , by $2.98 \times 10^{8} \mathrm{~m}^{3}$ $\left(42.67 \times 10^{6} \mathrm{~m}^{3} \mathrm{a}^{-1}\right)$ between 1992 and 1999 , and by $7.24 \times 10^{8} \mathrm{~m}^{3}\left(65.82 \times 10^{6} \mathrm{~m}^{3} \mathrm{a}^{-1}\right)$ between 1999 and 2010 (Fig. 4). The rate increase of lake volume between 1999 and 2010 was 1.5 times greater than that between 1992 and 1999, and 8 times greater than that between 1974 and 1992.

Similar variations of Longwei Co, Amur Co and Darngo Co Ngion were observed between the 1970s and 2010, but the

Table 1. Lake area $\left(\mathrm{km}^{2}\right)$ of Linggo Co, Longwei Co, Amur Co and Darngo Co Ngion at different stages

\begin{tabular}{lrcrc}
\hline & Linggo Co & Longwei Co & Amur Co & $\begin{array}{c}\text { Darngo Co } \\
\text { Ngion }\end{array}$ \\
\hline Early 1970s & 94.95 & 44.45 & 34.57 & 41.41 \\
& $(1974)$ & $(1973)$ & $(1971)$ & $(1971)$ \\
1976 & 94.75 & 38.99 & 29.07 & 38.11 \\
1992 & 97.59 & 26.39 & 18.18 & 29.90 \\
1999 & 101.35 & 45.36 & 29.76 & 34.54 \\
2006 & 109.33 & 53.96 & 47.97 & 47.93 \\
2010 & 115.21 & 56.24 & $109.2^{*}$ & $109.2^{*}$ \\
& & & & \\
\hline
\end{tabular}

*Amur Co and Darngo Co Ngion became a single lake in 2010 and the total area was $109.2 \mathrm{~km}^{2}$. variations for these three lakes were different from those in Linggo Co (Table 1; Fig. 3). Longwei Co, Amur Co and Darngo Co Ngion had areas of 44.45, 34.57 and $41.41 \mathrm{~km}^{2}$ respectively in 1973/1971, and between 1973/1971 and 1992 the lake areas decreased significantly by $18.06 \mathrm{~km}^{2}$ (40.63\%), $16.39 \mathrm{~km}^{2}(47.41 \%)$ and $11.51 \mathrm{~km}^{2}(27.80 \%)$ respectively. Thus, area changes of the three lakes were opposite in sign to that of Linggo Co before 1992. Between 1992 and 1999, the three lakes expanded dramatically by $18.97 \mathrm{~km}^{2}(42.68 \%), 11.58 \mathrm{~km}^{2}(33.50 \%)$ and $4.64 \mathrm{~km}^{2}$ $(11.20 \%)$ respectively. Between 1999 and 2006, they continued to grow by $8.60 \mathrm{~km}^{2}(19.35 \%), 18.21 \mathrm{~km}^{2}$ $(52.67 \%)$ and $13.39 \mathrm{~km}^{2}$ (32.33\%) respectively. After 2006, the area of Longwei Co increased by $2.28 \mathrm{~km}^{2}$, and the area of Amur Co and Darngo Co increased by a total of $13.30 \mathrm{~km}^{2}$. Owing to the small shoreline gradient, the rates of surface area change for the three lakes were greater than that of Linggo Co.

\section{Glacier changes}

The glaciers in the catchment of Linggo Co cover an area of $135 \mathrm{~km}^{2}$ or $7.4 \%$ of the basin area, and provide significant water inflow to Linggo Co. Between 1974 and 2007, the glacier area in the catchment of Linggo Co decreased by $3.22 \mathrm{~km}^{2}$ or $2.4 \%$. The rate of area loss decreased from $0.3 \mathrm{~km}^{2} \mathrm{a}^{-1}$ to $0.026 \mathrm{~km}^{2} \mathrm{a}^{-1}$ between 1974 and 1999 , but increased to $0.087 \mathrm{~km}^{2} \mathrm{a}^{-1}$ between 1999 and 2007 (Table 2). As a continental-type glacier, Puruogangri ice field retreated at a much slower rate than the average rate of $5.5 \%$ for TP glaciers between 1960 and 2000 (Kang and others, 2009).

The surface elevation difference of Puruogangri ice field varied from $-212 \mathrm{~m}$ to $132 \mathrm{~m}$, with a mean value of $-6.19 \pm 1.91 \mathrm{~m}$ between 1974 and 2000 (Fig. 5). The decline of surface elevation mainly occurred in glacier tongue

Table 2. Changes in glacier area $\left(\mathrm{km}^{2}\right)$ in the catchment of Linggo Co

\begin{tabular}{lccrrc}
\hline & 1974 & 1976 & 1992 & 1999 & 2007 \\
\hline Glacier area & 135.15 & $\begin{array}{c}134.25 \\
-0.9\end{array}$ & $\begin{array}{r}132.92 \\
-1.33\end{array}$ & $\begin{array}{r}132.74 \\
-0.18\end{array}$ & $\begin{array}{c}132.04 \\
-0.7\end{array}$ \\
\hline
\end{tabular}




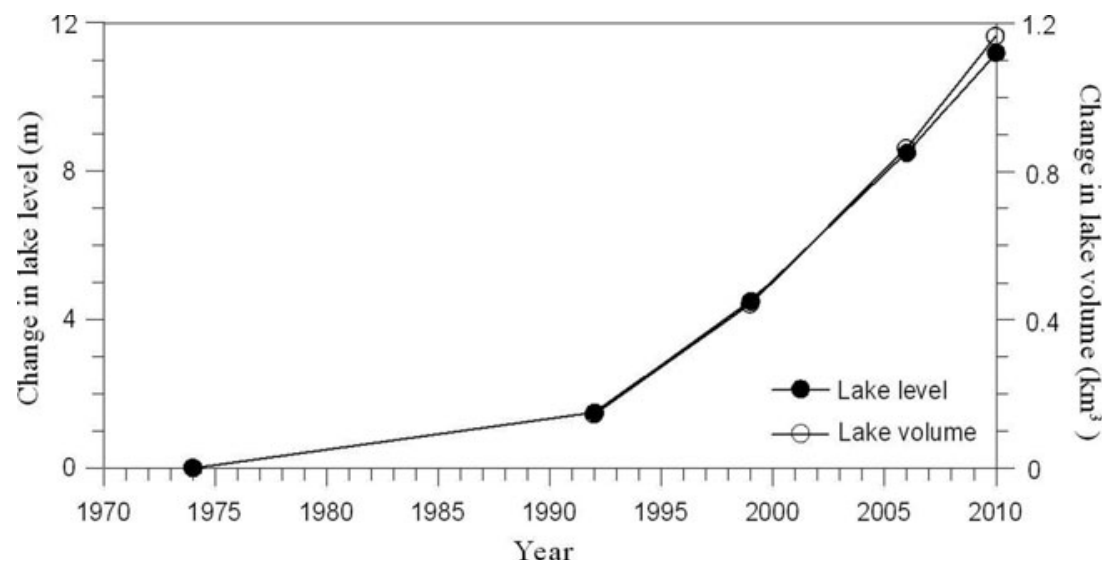

Fig. 4. Changes in lake level and volume of Linggo Co between 1974 and 2010, compared with 1974.

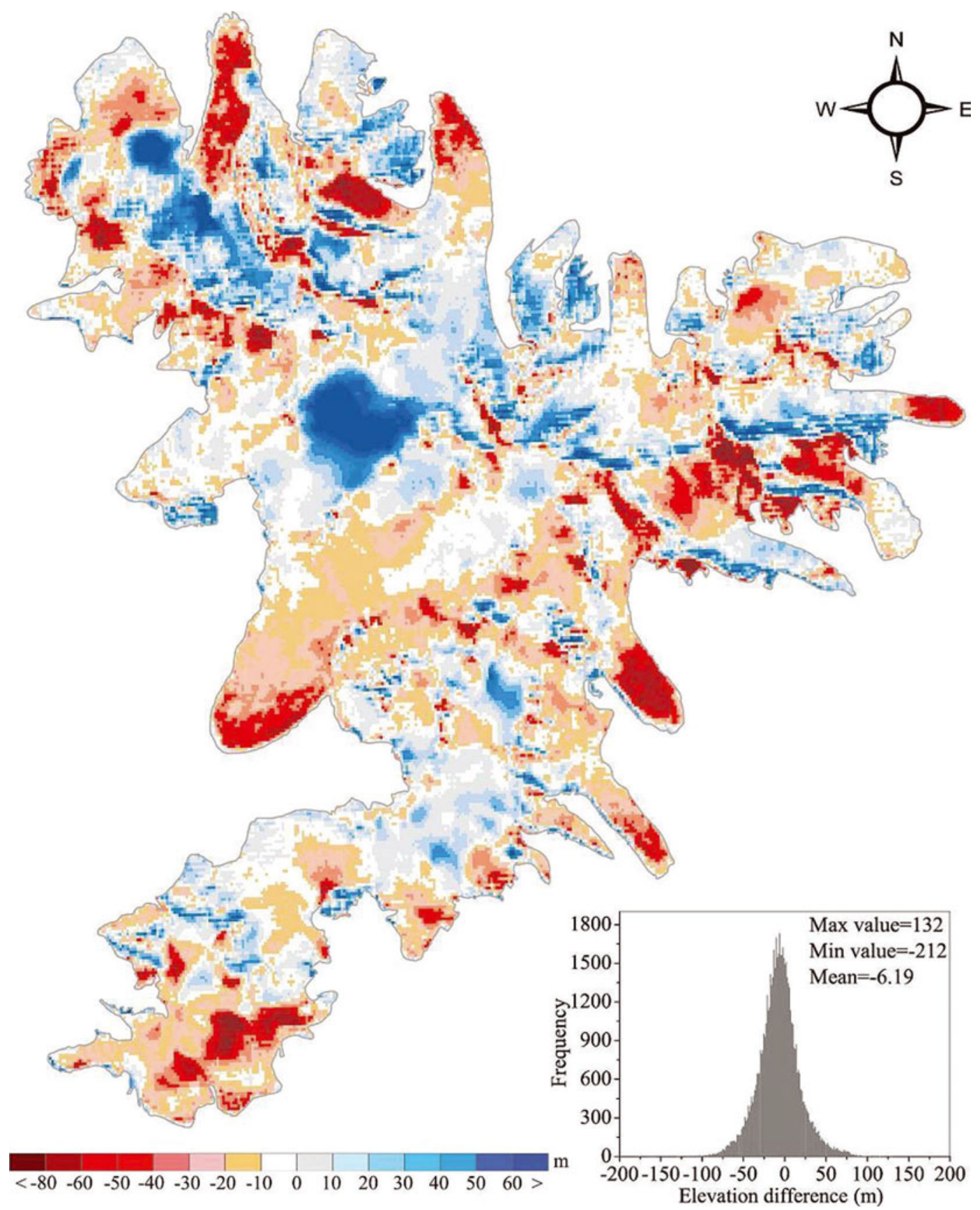

Fig. 5. The surface elevation difference of Puruogangri ice field between 1974 and 2000. The inset is the histogram of the SRTM DEM (2000) minus DEM10 (1974). Positive values indicate glacier thickening, and negative values indicate glacier thinning. 

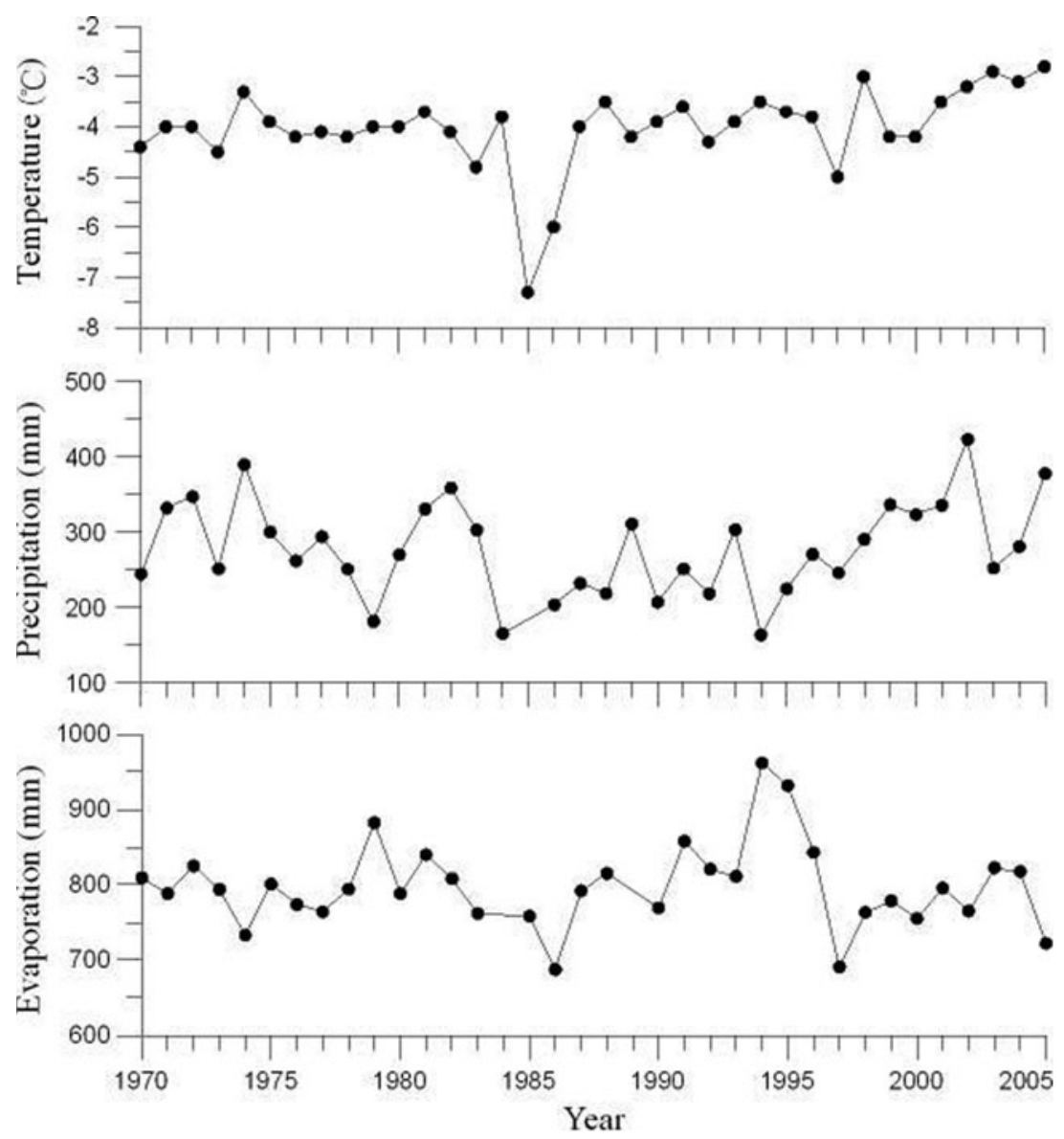

Fig. 6. Time series of annual temperature, precipitation and $20 \mathrm{~cm}$ pan evaporation between 1970 and 2005 at Tuotuohe meteorological station, which is located about $330 \mathrm{~km}$ to the northeast of Linggo Co (Fig. 1).

regions, and the increase in surface elevation mainly occurred in glacier interiors. The center of Puruogangri ice field is a wide and flat plateau with an area of over $150 \mathrm{~km}^{2}$ and an elevation exceeding $5800 \mathrm{~m}$ a.s.l. Despite climate warming, it is still an accumulation zone, while ablation has greatly increased in the lower glacier regions. Total glacier mass loss in the catchment of Linggo Co is calculated to be $(7.52 \pm 2.32) \times 10^{8} \mathrm{~m}^{3}$ w.e. between 1974 and 2000 .

There are only limited records of continuous glacier massbalance measurement on the TP due to its remote location and high elevation. On the central TP, the mass balance of Xiao Dongkemadi glacier $\left(33^{\circ} 04^{\prime} \mathrm{N}, 92^{\circ} 05^{\prime} \mathrm{E}\right)$ in the Tanggula Mountains has been monitored since 1989, and the results reveal that the average ice thickness increased by $1.08 \mathrm{~m}$ between 1989 and 1994, but decreased by $3.5 \mathrm{~m}$ between 1994 and 2002 (Pu and others, 2008). Long-term observations of Ürümqi glacier No. $1\left(43^{\circ} 05^{\prime} \mathrm{N}, 86^{\circ} 50^{\prime} \mathrm{E}\right)$ at the headwaters of the Ürümqi river show that glacier thickness decreased by about $8 \mathrm{~m}$ between 1958 and 2000 (Li and others, 2003). Based on the field surveys of glacier boundary utilizing differential GPS and glacier depth by ground penetrating radar, Ma and others (2010) calculated the mass balance of Kangwure glacier $\left(28^{\circ} 27^{\prime} \mathrm{N}, 85^{\circ} 45^{\prime} \mathrm{E}\right)$ in the central Himalaya to be $-7.5 \mathrm{~m}$ between 1974 and 2008 . Although Puruogangri ice field is an extremely continentaltype glacier (Shi and Liu, 2000), the mass loss was only slightly less than that of other glaciers on the TP during the past few decades, which indicates that continental-type glaciers also experienced significant mass loss, although the area change was much smaller than for maritime glaciers.

\section{Causes of lake growth}

For closed lakes, the main factors influencing the water balance include precipitation, evaporation and runoff. The annual precipitation at Tuotuohe station, located about $330 \mathrm{~km}$ northeast of Linggo Co, decreased significantly from 1970 to 1984, reached a mimimum between 1984 and 1995 and has increased considerably since 1997 (Fig. 6). The $20 \mathrm{~cm}$ pan evaporation showed high values between 1987 and 1996, and low values between 1997 and 2005. For the non-glacier-fed lakes, the lake area (Fig. 3) varied in the same pattern as the precipitation. The shrinking stage between the 1970s and 1992 corresponded to the decrease in precipitation, while the expanding stage corresponded to the increase in precipitation between 1998 and 2005.

Despite being in the same climate region, Linggo Co evolved differently from the other three lakes. The area of the three non-glacier-fed lakes in 2000 was close to that in the early 1970s, but shrank significantly between the 1970 s and 1992, indicating that the lake water experienced a considerable deficit. The water level of Linggo Co rose by $5.1 \mathrm{~m}$ and the lake volume increased by $5.0 \times 10^{8} \mathrm{~m}^{3}$ between 1974 and 2000. Assuming similar climate changes occurred in Linggo $\mathrm{Co}$, the lake growth was mainly attributed to the increased influx of glacier meltwater between 1974 and 2000. As we have shown, the glacier mass loss in the catchment of Linggo Co is calculated to be $(7.52 \pm 2.32) \times 10^{8} \mathrm{~m}^{3}$ w.e. between 1974 and 2000. The increase in lake volume of Linggo Co corresponded to $\sim 66 \%$ of the glacier mass loss during this period. This 
suggests about one-third of glacier meltwater was consumed by evaporation and recharged to groundwater, which is not a small portion of the water budget in the catchment of Linggo Co. We attribute this consumption to the significantly negative water balance between 1974 and 1992, which has been indicated by the significant shrinkage of the nonglacier-fed lakes.

Linggo Co and the other three lakes all expanded significantly between 2000 and 2010, which indicates that not only glacier mass loss but also climate change (i.e. an increase in precipitation and/or decrease in evaporation) contributed to the growth of Linggo Co. Many studies show that glacier mass loss accelerated during the past 10 years (Yao and others, 2004; Bamber and Rivera, 2007; Paul and others, 2007; Yang and others, 2008; Kang and others, 2009). Globally averaged ice mass loss between 1990 and 2004 was double that between 1960 and 1990 (Solomon and others, 2007). Here we assume that the glacier mass loss of the Puruogangri ice field between 2000 and 2010 was also double the loss between 1974 and 2000, and $70 \%$ of the glacier mass loss was transferred into Linggo Co. Based on these assumptions, we calculate the contribution of glacier mass loss to the lake-level rise of Linggo Co to be $3.6 \mathrm{~m}$, or about $60 \%$ of the total lake-level rise, between 2000 and 2010.

Comparing the contribution of glacier mass loss to lakelevel rise, we find that the glacier mass loss has a great impact on the rapid growth of Linggo Co. During the drier period of 1974-99, glacier mass loss was larger than the increase in lake volume because it not only increased the lake level of Linggo Co significantly, but offset the negative water balance (the decrease in precipitation and the increase in evaporation). Meanwhile, during the wetter period of 1999-2010, although the increase in precipitation and decrease in evaporation could have contributed considerably to the lake-level rise, glacier mass loss contributed more than half of the lake-level rise.

\section{CONCLUSIONS}

Based on water depth measurements in conjunction with remote-sensing and GIS techniques, we reconstructed the lake-level variations of Linggo Co, a glacier-fed lake on the central TP. Results show that the lake level increased by $1.5 \mathrm{~m}$ between 1974 and 1992, by $3.0 \mathrm{~m}$ between 1992 and 1999, and by $6.7 \mathrm{~m}$ between 1999 and 2010. Three other lakes in the surrounding region (i.e. Longwei Co, Amur Co and Darngo Co Ngion), which are mainly fed by precipitation, shrank between the early 1970s and 1992 and expanded significantly between 1992 and 2010. Despite being in the same climate region, Linggo Co evolved differently from the other three lakes.

As a lake supplied predominantly by glacier meltwater, the growth of Linggo Co was mainly due to the negative mass balance of the Puruogangri ice field. The glaciers in the catchment of Linggo Co decreased in area by $2.4 \%$ from 1974 to 2007, and their mean thickness decreased by $6.19 \pm 1.91 \mathrm{~m}$ between 1974 and 2000. These changes were associated with $(7.52 \pm 2.32) \times 10^{8} \mathrm{~m}^{3}$ of glacier meltwater runoff. This study indicates that glacier mass loss not only compensated for the negative balance of the lake water under a relatively drier climate, but also contributed significantly to the lake-level rise between 1974 and 2010.

\section{ACKNOWLEDGEMENTS}

This research was supported by the External Cooperation Program of the Chinese Academy of Sciences (CAS; GJHZ0960), the CAS/SAFEA (State Administration of Foreign Experts Affairs) International Partnership Program for Creative Research Teams (KZCX2-YW-T11), The National Natural Science Foundation of China (NSFC) project (40810019001, 40730101 and 41101062) and the NASA New Investigator Program (NNX06AE58G). We thank Pan Baolin, Dong Guocheng and Ma Qingfeng for conducting the fieldwork. We are also grateful to Graham Cogley and an anonymous reviewer for constructive comments on the manuscript.

\section{REFERENCES}

Bamber JL and Rivera A (2007). A review of remote sensing methods for glacier mass balance determination. Global Planet. Change, 59(1-4), 138-148

Berthier E, Arnaud Y, Kumar R, Ahmad S, Wagnon P and Chevallier $P$ (2007) Remote sensing estimates of glacier mass balances in the Himachal Pradesh (Western Himalaya, India). Remote Sens. Environ., 108(3), 327-338

Bian D, Bian B, La B, Wang C and Chen T (2010) The response of water level of Selin Co to climate change during 1975-2008. Acta Geogr. Sinica, 65(3), 313-319 [In Chinese with English summary]

Guan Z and 9 others (1984) Rivers and Lakes of Xizang: the series of the scientific expedition to the Qinghai-Xizang plateau. Science Press, Beijing [In Chinese]

Kang E, Liu C, Xie Z, Li X and Shen Y (2009) Assessment of glacier water resources based on the Glacier Inventory of China. Ann. Glaciol., 50(53), 104-110

Koblet T and 6 others (2010) Reanalysis of multi-temporal aerial images of Storglaciären, Sweden (1959-99) - Part 1: Determination of length, area, and volume changes Cryosphere, 4(3), 333-343

Li X, Yi C, Chen F, Yao T and Li X (2006) Formation of proglacial dunes in front of the Puruogangri Icefield in the central QinghaiTibet plateau: implications for reconstructing paleoenvironmental changes since the Lateglacial. Quat. Int., 154-155, 122-127

Li X and 9 others (2008) Cryospheric change in China. Global Planet. Change, 62(3-4), 210-218

Li Z, Han T, Jing Z, Yang H and Jiao K (2003) A summary of 40-year observed variation facts of climate and Glacier No. 1 at headwater of Ürümqi River, Tianshan, China. J. Glaciol. Geocryol., 25(2), 117-123 [In Chinese with English summary]

Liu J, Wang S, Yu S, Yang D and Zhang L (2009) Climate warming and growth of high-elevation inland lakes on the Tibetan plateau. Global Planet. Change, 67(3-4), 209-217

Ma L,Tian L, Pu J and Wang P (2010) Recent area and ice volume change of Kangwure Glacier in the middle of Himalayas. Chinese Sci. Bull., 55(20), 2088-2096

Nuth C and Kääb A (2011) Co-registration and bias corrections of satellite elevation data sets for quantifying glacier thickness change. Cryosphere, 5(1), 271-290

Paul F, Kääb A and Haeberli W (2007) Recent glacier changes in the Alps observed from satellite: consequences for future monitoring strategies. Global Planet. Change, 56(1-2), 111-122

Pu J, Yao T, Wang N, Ding L and Zhang Q (2002) Puruogangri ice field and its variations since the Little Ice Age of the northern Tibetan Plateau. J. Glaciol. Geocryol., 24(1), 87-92 [In Chinese with English summary]

Pu J and 6 others (2008) Rapid decrease of mass balance observed in the Xiao (Lesser) Dongkemadi Glacier, in the central Tibetan Plateau. Hydrol. Process., 22(16), 2953-2958 
Qin D, Liu S and Li P (2006) Snow cover distribution, variability, and response to climate change in Western China. J. Climate, 19(9), 1820-1833

Racoviteanu AE, Williams MW and Barry RG (2008) Optical remote sensing of glacier characteristics: a review with focus on the Himalaya. Sensors, 8(5), 3355-3383

Reuter HI, Nelson A and Jarvis A (2007) An evaluation of voidfilling interpolation methods for SRTM data. Int. J. Geogr. Inf. Sci., 21(9), 983-1008

Schmidt S and Nüsser M (2009) Fluctuations of Raikot Glacier during the past 70 years: a case study from the Nanga Parbat massif, northern Pakistan. J. Glaciol., 55(194), 949-959

Shi Y (2001) Estimation of the water resources affected by climatic warming and glacier shrinkage before 2050 in western China. J. Glaciol. Geocryol., 23(4), 333-341 [In Chinese with English summary]

Shi Y and Liu S (2000) Estimation on the response of glaciers in China to the global warming in the 21st century. Chinese Sci. Bull., 45(7), 668-672 [In Chinese]

Solomon S and 7 others eds (2007) Climate change 2007: the physical science basis. Contribution of Working Group I to the Fourth Assessment Report of the Intergovernmental Panel on Climate Change. Cambridge University Press, Cambridge

Sun H, Liao K, Pan Y and Wang J eds (1990) Atlas of the QinghaiTibet plateau. Science Press, Beijing [In Chinese]

Wan W, Xiao PF, Feng XZ, Li H, Ma RH and Duan HT (2010) Remote sensing analysis for changes of lakes in the southeast of Qiangtang area, Qinghai-Tibetan plateau in recent 30 years. J. Lake Sci., 22(6), 874-881 [In Chinese with English summary]

Wang W, Yang $X$ and Yao $T$ (In press) Evaluation of ASTER GDEM and SRTM and their suitability in hydraulic modelling of a glacial lake outburst flood in southeast Tibet. Hydrol. Process, 26(2), 213-225 (doi: 10.1002/hyp.8127)

Yang W, Yao T, Xu B, Wu G, Ma L and Xin X (2008) Quick ice mass loss and abrupt retreat of the maritime glaciers in the Kangri Karpo Mountains, southeast Tibetan plateau. Chinese Sci. Bull., 53(16), 2457-2551

Yao TD, Wang YQ, Liu SY, Pu JC, Shen YP and Lu AX (2004) Recent glacial retreat in High Asia in China and its impact on water resource in Northwest China. Sci. China D, 47(12), 1065-1075

Yao T, Pu J, Lu A, Wang Y and Yu W (2007) Recent glacial retreat and its impact on hydrological processes on the Tibetan Plateau, China, and surrounding regions. Arct. Antarct. Alp. Res., 39(4), 642-650

Yao T and 7 others (2010) Glacial distribution and mass balance in the Yarlung Zangbo River and its influence on lakes. Chinese Sci. Bull., 55(20), 2072-2078

Ye Q, Zhu L, Zheng H, Naruse R, Zhang X and Kang S (2007) Glacier and lake variations in the Yamzhog Yumco basin, southern Tibetan plateau, from 1980 to 2000 using remotesensing and GIS technologies. J. Glaciol., 53(183), 673-676

Ye Q, Yao T and Naruse R (2008) Correspondence. Glacier and lake variations in the Mapam Yumco basin, western Himalaya of the Tibetan Plateau, from 1974 to 2003 using remote-sensing and GIS technologies. J. Glaciol., 54(188), 933-935

Yi C, Li X and Qu J (2002) Quaternary glaciation of Puruogangri the largest modern ice field in Tibet. Quat. Int., 97/98, $111-121$

Zhu L, Xie M and Wu Y (2010) Quantitative analysis of lake area variations and the influence factors from 1971 to 2004 in the Nam Co basin of the Tibetan plateau. Chinese Sci. Bull., 55(13), 1294-1303

MS received 24 January 2011 and accepted in revised form 19 August 2011 